\title{
Exploring the South African Post-Apartheid Poverty Situation and Proposing Measures to Mitigate the Status. A Literature Review
}

\author{
Prof. S. M Kang'ethe \\ University of Fort Hare, Department of Social Work and Social Development \\ Box X1314, ALICE. 5700, South Africa \\ Email: skangethe@ufh.ac.za \\ Mafa Itai \\ Masters of Social Work Student, University of Fort Hare \\ Email:200909691@ufh.ac.za
}

\section{Doi:10.5901/mjss.2014.v5n15p449}

\begin{abstract}
Despite the fact that South Africa has remained an economic powerhouse, it is striking to come into grips with the reality that millions are swimming in a sea of poverty, while a larger percentage are food insecure, not knowing where their next meal will come from. This is due to an array of challenges such as unemployment and individuals' unemployability due to lack of skills. The aim of this article is, through a review of literature, to discuss the state of poverty in South Africa and suggesting possible strategies to mitigate the effect. The article recognizes the following groups of people as most vulnerable and prone to immense poverty: the children, women, the aged, and the disabled. It has also identified the following efforts that can avert poverty in South Africa: discharge of social welfare grants, implementation of free housing programmes such as the Reconstruction and Development Programme (RDP), and free and accessible education. The article has also identified the following possible handicaps to poverty alleviation: dependence syndrome, state of crime and corruption, polarization between the rich and the indigent, and the discharge of social welfare grants. The article suggests the following as possible solutions to poverty alleviation: tightening the loopholes to annihilate criminality, promote women and youth empowerment, and foster a collaboration between the governments and communities.
\end{abstract}

Keywords: Apartheid, indigent, corruption, Millennium Development Goals, Transparency International, unemployment, unemployability, Government, crime, Interpol

\section{Problem Statement}

Viewed from whichever angle or lenses, poverty poses social, physical, financial and emotional predicament that puts individuals in a state of jeopardy. It deprives and sometimes pushes the victims to grapple in getting even the most basic needs as explained by the Maslow Hierarchy of needs (Wahba \& Bridwell, 1976). Poverty wreaks individuals' capacities, capabilities, thinking and encapsulates the individuals into a state of despondency, ineffectiveness, lowers their creativity and independence, and places their confidence at its lowest ebb. Perhaps the most destructive aspect of poverty is its capacity to thwart people's hope, dreams and vision. Poverty in many countries usually affects women and children. This inevitably promotes gender inequality while children caught in the poverty trap may fail to negotiate a good future. This is because they are usually not accorded a better opportunity to do well as long as the environment of poverty hangs in their necks. Since poverty is a real challenge two decades after the independence dispensation, with of course many horrendous and pinching effects manifesting, it is critical that the environment of poverty is critiqued with the hope of coming up with insights that can possibly strengthen the current policy environment that the government is exploiting to tackle poverty.

\section{Methodology}

The article has benefitted immensely from an array of literature from various scholars commenting on the poverty situation in South Africa. This has made the researchers to constructively engage in debates and discourses that have critically analyzed the poverty situation in South Africa and also suggested possible strategies to remedy the situation. It has also benefitted from journals and other media based publications on the state interpreting or commenting on poverty in South Africa; and also the researchers' intuitive engagements. 


\section{Background and Introduction}

World-wide, people talk of latest news all the time. However, despite being the centre of attention since the existence of humanity, poverty is still claiming the spot light in many headlines especially in the developing countries. This is usually due to its adverse nature. Gilbert (2004) supports this by pointing out that about 2.8 billion of the people around the world live in absolute poverty, with $40 \%$ of those that belong to the Sub-Saharan Africa acutely lacking safe water to drink. South Africa as a developing country also falls prey to poverty, humanity's worst enemy (Kange'the \& Mafa, 2014). Prior to the 1994 independence, South Africans especially of African race underwent a horrendous and pinching life because of the inhuman restrictions and policies that were callously imposed on them by their erstwhile colonizers (Reddy \& Sokomani, 2008). In fact, they were treated as aliens and foreigners in their own native land. Such legislative acts created a noticeable lacuna verge between the whites and non-whites, with Africans cornered to the poor pole (White Paper for Social Welfare, 1997). Although there have been significant changes in the lives of the blacks, more so that they are free, it remains an incontrovertible fact that umpteenth, the government of South Africa is still struggling to level out this imbalance (Economic Report on Africa, 2005). It is true that the brutal apartheid era sucked out the strength and the determination out of the many Africans. However, crying over split milk is evidently a non-constructive exercise. Hence forth, it is not the thrust of this article to probe into experiences that transpired during the apartheid epoch, but rather to assess the current plausible poverty alleviation efforts. For example, while South Africa's peculiar inequalities allow the affluent minority to benefit from privatised medical, educational and security services, the pauperised majority is forced to depend on the state for social security (Reddy \& Sokomani, 2008). Hence, the participation of South Africa in the Millennium Developmental Goals (MDGs) forum is a crystal clear indication that the government is practically engaged in the poverty reduction schemes (Economic Report on Africa, 2005). This is why the government of South Africa especially through its policy agenda such as Vision 2014 is strongly working to bring down poverty and all its manifestations. Whether the government is gaining or losing ground in the war to eradicate or reduce poverty and its consequent spinoffs is the focal point of this article. Perhaps the irony is the fact that since South Africans believe that they have a legal right not to be poor, this make them to demand the government to take the responsibility of providing the needs of the citizens that cannot, on their own, swim out of poverty.

\section{Poverty Stricken Groups in South Africa}

\subsection{The children}

It is an incontrovertible fact that in most developing countries, children and usually women bear the most brunt edge of poverty. Perhaps this is because children are dependents and therefore in dire need for support, care and love (Ward and Eyber, 2009). A child is defined as an individual who is below the age of 18 , financially and emotionally protégé on guardians (Kotch, 2013). Socially, legally, biblically or otherwise, children ought to be sheltered under capable wings in order for them to realise their potentials and overall functioning. Looking up to someone always brings up a sense of desperation which means that one's livelihood will solely be in the hands of another person. Children are economically incapacitated to cater for their own financial needs as they cannot get employed. As such, they tend to be susceptible to various circumstances, often not of their own making. Boyden (2003) as cited in Ward and Eyber (2009) comments that the dominant idea of childhood is universally built on notions of vulnerability and helplessness. This evidently explains the outrageous prevalence of child poverty, not only in South Africa, but across the globe. Kotch (2013) is of the view that poverty is associated with morbidity, behavioural and emotional disorders which may hinder the holistic functioning of children even in their adulthood. Ultimately, these children's capabilities, dreams and abilities are frustrated by poverty. No wonder children are labelled as a soft spot, an easy target of poverty in its manifold manifestations. This then reflects the seriousness, susceptibility and vulnerability of children to poverty, and the degree of deprivation thereof. Although the government is working round the clock to contain the horrendous impacts and effects of child poverty, most of the characteristics above may capture some South African children.

\subsection{The women}

A woman can carry the whole world on her shoulders if she has to in the same manner that she carries a child for the lengthy nine months. It might be this sacrificial act of kindness and love that has however contributed to her state of feminization of poverty (Ditmore, 2011; Musekiwa, 2013). Women are known to stay at home doing domestic chores and thereby depriving themselves of the opportunity to work and finance their lives. Even though this is slowly fading away 
due to societies generally embracing modernization, westernization and urbanization (Kange'the \& Mafa, 2014), it is also for this same reason that many women are illiterate since child bearing restrict their capability to pursue further education or other kind of life bettering activities as their male counterparts (Kanchense, 2008). Low levels of marketable skills weaken their ability to compete on the economic market. It can then be safely said that without proper and relevant skills, women are pushed on the bottom pile into the semi-skilled file or even the informal sector. It is then a combination of such factors mentioned above that make women vulnerable to poverty that Chant (2006) disinters as feminization of poverty. In her research, she argues that women generally bear an irrationally immense saddle of poverty than their male counterparts. In simple terms, this means that more women in the whole world including South Africa are poorer than their male counterparts. In South Africa, the apartheid era policies aggravated the situation by segregating women, a racial exercise that almost crippled not only South African women but the whole nation. Many women especially in the rural areas struggle to feed themselves as well as their families (Scott, 2008).

\subsection{The aged persons}

It is often said that old age is a privilege and a blessing from God (MacArthur 1997). Of course this is true as it allows the individual to experience, explore and witness numerous events that may enrich lives. According to Kang'ethe (2009), aging is an entropic disorder which as senility of individuals takes toll, is associated with decline in cognitive, emotional and physical energies. This of course negatively affects one's productivity. However, it is also true that old age comes with incapacitation, ill health and a loss of one's independence (Reddy \& Sokomani, 2008). As old age takes its toll, the elder's immune system deteriorates exposing them to assorted diseases such as heart problems, blood pressure and even mal-functioning of vital organs. Due to the fact that the apartheid era deprived the majority of people in South Africa from exploring available economic opportunities (White Paper for Social Welfare, 1997), many old people have very limited financial back-up reserve to help them during the very hard times (Scott, 2008; Hanlon, Barrientos \& Hulme, 2010). The perforated financial pockets and many-figured medical bills squeeze life almost out of the elderly making them even more exposed to the merciless effects of poverty. Although South Africa welfare policy adequately covers the elderly, the grants can barely sustain them. Perhaps they paltry afford them to meet the bottommost rank in the Maslow hierarchy of needs (Wahba \& Bridwell, 1976). Even to those who receives retirement benefits, they get peanuts that paltry covers even the most basic aspects of their lives.

\subsection{The disabled}

Of cause being disabled does not mean inability. However, it is an incontrovertible fact to acknowledge that disabled people are functionally challenged in an array of other aspects of their lives. As a result, their economic competitive edge is generally a little weaker than that of able-bodied individuals (Reddy \& Sakomani, 2008). This does not imply that disabled people are incapable or ineffective individuals. But it is good to point out that their capacities and capabilities depends on the degree to which they are physically or mentally challenged with some who can carry on with their daily chores like any other person, or even better. What makes them susceptible to poverty is the fact that they are dependent on other people for some things (Kotch, 2013), for example the blind who need someone to lead them the way. Those with amputated legs or arms also need other people to help them to get by each day. Dependability therefore always comes with a certain degree of vulnerability (Ward and Eyber, 2009). Hence forth, the disabled can safely be said that they are indeed a group that is likely to be poverty stricken..

\section{Governmental Efforts to Avert Poverty in South Africa}

\subsection{Social security grants}

South Africa's beleaguered history ultimately gave birth to the government that joined forces in an effort to eradicate poverty. Initiatives such as the need to discharge the social security grants led to the formation of the Department of Social Development (DSD) and the South African Social Security Agency (SASSA), the departments leading in the poverty eradication forum (Reddy \& Sokomani, 2008). Taking a step back, the term 'social security' envelops various aspects of both public and private efforts aimed to bring relief to the poverty stricken groups (Skweyya, 2007). In short, social assistance is meant to support human development to exit poverty and thereby disrupting the intergenerational transmission of chronic poverty (Shephered, Wadagodapitiya \& Evans, 2011). This form of relief can boost the independence of any persons whose earning ability has permanently ceased, is being interrupted, is never developing, or 
being exercised only at unacceptable social cost making individuals unable to avoid poverty (White Paper for Social Welfare, 1997). The main purpose for the institution of the social grant was to eradicate and curb the effects of poverty among the vulnerable groups. The government came up with this innovation as a way of bridging the gap between the rich and the poor. This also involves correcting the wrongs that has been brought about by the former racist government that sought to impoverish the blacks. The apartheid state, however, aggravated the economic and social status of the disabled, the elderly, the children and women (Hanlon et al., 2010). These are the groups that are given the welfare grants. This exercise has indeed made a significant difference in the lives of the people that are receiving aid. Although it can be argued that the amount is little, but these researchers contend that half a loaf is always better than nothing at all. These amounts give the recipients a starting point to surmount the horrendous and pinching effects of poverty.

\subsection{Free Housing (Reconstruction and Development Programme (RDP) Houses)}

The late former President Nelson Mandela emphasised on social equality, basic services for all and affordable housing. According to this exceptional leader, all South Africans have the right to proper housing (Manomano, 2013). As such, the government sought to build numerous houses a year to meet the needs of the majority South Africans who have no decent roofs over their heads (White Paper for Social Welfare, 1997; Kang'ethe \& Manomano, 2014). Obviously, building a house involves a lump sum of funds. Since, realising this goal entailed huge amounts of money. This, then prompted the government to engage in constructing low-cost houses through a programme known as the Reconstruction and Development Programme (RDP). According to Hanlon et al., (2010), the RDP housing programme can be seen as statesubsidised, low-cost houses aimed at reconstructing South Africa after the apartheid destructive era. To these researchers, this presents a state of panacea. Henceforth, this initiation commenced in 1994 soon after South Africa attained its independence. The country has witnessed a tremendous transformation of indigent people as they occupied decent houses with electricity and clean water (Mbuli, 2008). Poverty eradication is then the only practical way of ensuring that South African's dignity is restored and equality ensured. Closely related to free housing is affordable and almost free education. Even though several complaints about the quality of these houses has been received across all the regions in the country, at least people have houses from which to launch their grievances and complaints and their availability richly fulfils the most basic ladder of the Maslow hierarchy of needs, provision of shelter (Wahba \& Bridwell, 1976).

\subsection{Free and accessible education}

It is an incontrovertible fact that once you educate a nation, you secure the development and future of a nation. Free and accessible education for all South Africans came about in an effort to level out social inequalities that were given birth to by high levels of illiteracy especially among women and the African child (Hanlon et al., 2010). The policies and regulations that were introduced and implemented by the former government naturally deprived the majority of South Africans of their rights to basic education. In order to correct this abominable act, the government promoted the educational sector by making basic education more accessible and affordable (White Paper for Social Welfare, 1997). This has included the numerous bodies that offer bursaries for tertiary education. Statistically speaking, there seem to be a significant improvement as the Department of Basic Education reported that 2013 recorded the highest Matric pass rate of 75\%, supported by the number of the matriculants reaching 562112 (eNCA 17:30 hrs NEWS, 06/01/2014). This is indeed an enormous difference considering that in 1994, the pass rate was only $58 \%$. As much as the achievement deserves to be celebrated and emphasized on, there is also a dire need for further exploration on the pupils who do not make it to grade 12, those that fail in the matric examinations and those who fail to enrol in the universities. It is therefore crucial for the government to remember that illiteracy is not just a matter of reading and writing, but the ability to possess the skills that can be relevant to the job market. Mr Fick, the commentator of eNCA NEWS on 06/01/2014 argued that there is dire need to further find out whether or not there are jobs for those who matriculate or graduate. Hence, vocational skills need to be incorporated as well, as they tend to accommodate those that are academically challenged.

\section{Shortcomings of the Post-Apartheid Poverty Alleviation Efforts}

\subsection{Dependency syndrome}

Even though it is safe and healthy to depend on someone for something, this does not denote total reliance on others for one's welfare especially when an individual is capable of doing something for his/her economic security (Shepherd et al., 
2011). The social grant system in South Africa has been widely criticised for planting a dependency syndrome which makes people to lose their inclination to improve their living standards (Shepherd et al., 2011). Putting facts into perspective, the money the government uses for grants is taxed out of the working population of South Africa. Although it is to help those who are in need, the majority of the beneficiaries are intensely abusing these well-intended social grants. As such, many people make efforts to qualify under beneficiaries of such programmes instead of striving to initiate strategies and mechanism that would promote financial independence and stability (Potty, 2012). In Zimbabwe, although there is an unemployment rate of over $80 \%$ (Kanchense, 2008) and a globally known political upheaval, the citizens are resourceful as they attempt to curb poverty. Zimbabweans are all over the world as supported by the findings of Makina \& Kanyenze (2010), who revealed that over 3040000 have migrated in pursuit of greener pastures. Instead of them waiting up on the government to give them fish, they have gone fishing themselves. Also, the child support grant has been said to be promoting sexual activity among teenagers and subsequently leading to out-of-wed births and the spread of the HIV pandemic (Potty, 2012). Dependence as a syndrome, therefore, is economically detrimental to the nation as a whole especially when the population that is taxable is increasingly becoming smaller while the number of tax recipients is burgeoning day-in-day-out. The process is also a recipe for uncontrollable inflation. Even though many people are significantly benefiting, dependence syndrome remains the most destructive seed that has been planted in the minds of the social grant recipients.

\subsection{Criminality and corruption.}

South Africa ranks among the countries with significantly scary crime rates. According to Interpol, South Africa was ranked the second most dangerous country in the world (Blakemore, 2003). The most common of these crimes include violent crimes such as robbery, rape and white-collar fraud. It is really sad to begin to look at the cases of embezzlement and fraudulent activities that have been levelled against the prominent people especially those in various cadres of leadership. This river of lawlessness, greed and selfishness is unfortunately flowing from the very pinnacle of the state and thereby creating an environment where the whole country is in disarray (Mbuli, 2008). Periodically, the frustrations emanating from various kinds of corruption have prompted community outbursts and reactions through violent demonstrations some of which have turned xenophobic with angry mobs turning to loot the foreign owned shops and other properties. On the other hand, they have a dependence mentality and hence engage in destructive exercises as their way of claiming their slice of the economic cake. Also, some social welfare stations have been reported of having 'ghost' social grant beneficiaries. For example Mail \& Guardion (1997 cited in Reddy \& Sokomani (2008) exhumed that about R1.4 billion was lost to corruption and this constituted about $2.46 \%$ of the total funds allocated to this budget. Moreover, the Government Personnel Salary System (PERSAL) disinterred that about 41000 public servants across government departments were receiving salaries as well as social grants simultaneously (Reddy \& Sakomani, 2008). These are non-existent people who are corruptly registered as bonafide grant recipients. This state of affairs presents a very frustrating scenario to especially the taxpayers who are handsomely taxed in order to meet the national budget of maintaining welfare generally. It is unfortunate if South Africa, one of the biggest economic powerhouse of Africa should go the route of other filthily corrupt countries as per the reports of the Transparency International.

\subsection{Polarization of the poor and the rich}

South Africa is widely known as Africa's capital city because of its outstanding infrastructure in Sub Saharan Africa (Mbuli, 2008). This is supported by the fact that many Africans seek opportunities and financial openings from South Africa with Zimbabwe alone having over 2 million immigrants in the country (Makina \& Kanyenze, 2010). One can only wonder then why this country is said to be poverty stricken if indeed it is a feeding basket of many African nations. The answer to this question is what can be termed as the polarisation of the rich and the poor (White Paper for Social Welfare, 1997. This means that there is an increasing verge between the wealthy and the needy. For example citizens in Gauteng stand to benefit more than those in the Eastern peripherals because of the skewed apportionment of the opportunities and funds (Mbuli, 2008). Furthermore, the Democratic Alliance (DA) politician also highlighted that the Western Cape also lamented over the realisation that Cape Town was now a migration victim of people from the Eastern Cape (eNEWS @ 18:00Hrs, 21/02/2014). Her speech reflected an imbalanced apportionment of opportunities and resources as some provinces scramble for survival. This explains why some people are disgustingly wealthy while others are excruciatingly poor. So the right question could be; is it that the cake is too small or that the one entrusted with the cutting knife is dishonestly and unjustly apportioning it? While the rich live in luxurious and immensely expensive villas in some parts of Capetown, the majority poor are living in tinned houses (mekhukhu) in places such as Khayelitsha 
township of the Western Cape Province (Mbuli, 2008). The two sets of people live in starkingly and diametrically opposed states of environments. Although one may argue that the future lies in one's hands, however, the structures, polices and system of the nation may be creating such a gap (Potty, 2012). Although the apartheid era has unfortunately paved a way to this poignant situation, it is up to the present government to implement corrective, remedial and affirmative strategies that will significantly lead to equality for all.

\subsection{Discharge of social welfare grants}

Succinctly, social grants involve long term financial commitments that are tax-based and this involves a huge amounts of money. Recently, South Africans have helplessly and regrettably watched the falling of their Rand on the international market with an exchange of US\$1 to RZA 11,60 (ZBC NEWS 20:00 hrs, 04/01/2014). Slowly but surely, the prices are significantly increasing as the family basket is now requiring a few more R100 notes for the same groceries. Although inflation in South Africa is not equitable to the 2008-2009 Zimbabwean case, the situation heralds that the economy is in trouble. With so many people in need of governmental aid, high levels of unemployment and an increased cost of living that has pushed even the once financially comfortable families into the impoverished lane, the country appears to be sliding into a state of horrendous and pinching economic challenges (Bond, 2009). Power cuts, retrenchments and company liquidation are beginning to be seen as normal in the South African economy (World Bank, 2014). The policies and the economy are failing to create employment and even securing those on the pay cheques (White Paper for Social Welfare, 1997). With little economic growth, investors and job opportunities, it seems like the South African economy is being forced to carry a much heavier load that it is designed to, even though life has generally improved since independence.

\section{Way Forward to Effectively Curb Poverty in South Africa}

\subsection{Tightening the loopholes to control criminality}

Crime as the commonly manifesting social ill in the Republic of South Africa has to be slashed back to size if the country's reputation is to be restored and retained (Blakemore, 2003). The international image of the nation is at stake because of the despicable rates of criminal activities that almost cost the nation the privilege to host the 2010 World Cup football matches. Understanding that there is a committee that has been instituted to investigate corruption in governmental positions, more practical measures are necessary at individual level since charity begins at home. There is also a dire need for a close scrutiny on the social security system, the implementing measures that will allow transparency, accountability and efficient delivery of services to the people of South Africa (The White Paper for Social Welfare, 1997). Making an example is another way of ensuring that everyone lives in the confinement of the formal laws. The South African justice system is known for its numerous flaws. Documents vanish, medical paroles are given to almost anyone who wishes to apply for them and prominent people's cases are swept under the never-opened carpets (Blakemore, 2003). Unless these practical measures are properly employed, South Africans will continue to face numerous hurdles on their way such as poverty, violence and inflation because corrupt people are responsible for fattening their pockets at the expense of the welfare of the nation.

\subsection{Promote women empowerment and economic freedom}

The feminization of poverty as put forward by Chant (2006) clearly reflects the susceptibility of women to deprivation of many kinds and thereby opening doors and conditions such as HIVIAIDS and abuse. Since women are evidently on the weaker side of the equation, to balance this off, women ought to be empowered. Empowerment, however, does not mean disempowering men but rather a fair exercise that seeks to create well-deserved spaces for women as equal South African citizens. The best way to do this is first of all seek mental emancipation to create a developmental mindset (Kange'the \& Mafa, 2014). This is crucial because freedom starts with one's perception and view of things. There are many women in mental prisons than those that are in physical and visible jails. According to Alao (2012), this can then be followed by advancement in women's educational skills that will accommodate those who are mentally challenged with options such as practical and marketable skills. High illiteracy rates among women can only be cut down if women are encouraged, empowered and supported to advance in their different academic fields, and thereby probably enabling them to occupy the positions that are widely dominated by men (Yarber \& Sharp, 2010). In this way, male dominance will be diluted bringing in a neutral platform that is ideal for social and economic development, a bullet into the heart of poverty. 
These researchers believe that if the socio-economic terrain between men and women is made level, perhaps women can be as competitive as their male counterparts.

\subsection{Promote youth empowerment}

The youths in South Africa are the group commonly affected by unemployment, ultimately leading to poverty (World Bank, 2014). Due to the fact that most of these youths are raised by the single mothers (UNAIDS, 2004), they are deprived of the educational opportunities because of the dual effects of child poverty and the feminization of poverty concept. It is then imperative for the government to draft policies that address the predicaments that the youths of South Africa are facing today (Kange'the \& Mafa, 2014). The youths are the future leaders of tomorrow. However, for this vision to be a reality, it is the duty of the government together with other relevant stakeholders to ensure that the necessary resources are within reach for these young men and women. According to Moyo (2005), without the necessary marketable skills and educational qualifications, these youngsters have the tendency of initiating their own means to obtain what they want or need, the grey activities that are usually in conflict with the law such as criminal activities. It is therefore advisable for the government to prevent these tragic social ills instead of waiting up later to cure the symptoms, an exercise which is always costly to the state and the society. Succinctly, prevention is better than cure (Zastrow, 2010). This then calls for all the concerned parties to bring their heads together, put their differences aside and get back on the drawing board to implant policies and strategies that ensure progression for the nation. After all, equality for all was the central motive encouraging freedom fighters to forge forward to eradicate the apartheid era which benefitted only a handful at the expense of the majority of people.

\subsection{Collaboration between the government and communities}

It is high time that the governments desert the medical kind of approach to social interventions (Saleebey, 2005). Poor people are not like a sick person that needs a prescription from a doctor to calm down the fever. In fact, the poor are the ones wearing the shoes and they know exactly where it hurts. As such, it only makes sense for them to be consulted, effectively participating in such matters since they directly concern them (Zastrow, 2010). Developmental projects for example should not just be erected and the communities are expected to be grateful. Instead, in order for these grassroots people to appreciate and own such developmental efforts, they need a platform to make their voices heard in terms of their unmet needs (Kange'the \& Mafa, 2014). That way, priorities can be put in check saving the government from wasting money on something the communities do not need. The fact that the communities experiences the challenges on a daily basis gives them the upper hand to know exactly the corrective measures that can avert poverty, and thereby how to uproot it permanently (Moyo, 2005). Hence, transparent, honest participation and partnerships between communities and the government are essential in tackling poverty and other horrendous and pinching effects that are concomitant with poverty.

\section{The Theoretical Framework}

\subsection{The Structural theory}

The structural theory is concerned with the organization of a nation in relation to the pervasiveness and the root of poverty (Brady, 2009). This explains why it is simultaneously termed the environmental theory. Vicente (2005: 4) in this regard indicates that "Poverty is not the product of individual processes or particular pathologies or psychologies, but rather a product of relational processes of complex power relationships that produce, maintain and reproduce it." The theory, therefore, deviates from the individualistic view on poverty as it accommodates and considers those factors external to an individual such as South African policies and the apartheid era. This theory then looks at the economic, political and social systems which limit people's choices, resources and ultimately their opportunities (Bradshaw, 2005). A structure is defined by Brady (2009) as a set of labor market opportunities and demographic vulnerabilities that explain the population's rate of poverty.

This theory is largely applicable to Africa and more specifically to South Africa case as a developing country characterised by corruption, violence, high crime rates and a non-transparent government. Rodgers-Dillon (2004) points out that the unavailability of legitimate opportunities and an unfavourable economic ground which restricts employment opportunities leads to the manifestation of poverty in various forms such as deprivation and poor living conditions especially among the vulnerable groups. This is evident in that the citizens are victims of the nation's structure and that 
their wellbeing or fate is not in their hands as the individualistic theories emphasise. In this regard, Rodgers-Dillon (2004) argues that a person may do everything humanly possible but still be poverty-stricken because of reasons beyond him or her. For example, lack of work to those who are willing and able to work. In South Africa, the apartheid era and current unemployment rates are directly linked as the indigent are segregated and out-skirted in matters that concern political processes and economic decisions (Bradshaw, 2005). As a result, the structural theory then outlines that the only way to escape poverty is by overthrowing the structural theory that exacerbates poverty among its citizens. This can be through reformulating more accommodating policies as well as grassroots participation in issues that concern the general public such as poverty eradication among vulnerable South Africans.

However, the structural theory fails to notice the resilience of human beings especially that of indigent citizens. Despite the petite amounts of social grants, the impoverished groups are still able to sour above the circumstances as they have learnt to grow a thicker skin. Planning and working hard is the gate way out of poverty and not depending on the hand-outs or engaging in destructive behaviour. If social grants are corroborated with practical development, South Africa can be seen soon as the Canaan of Africa, where honey and milk overflows.

\section{Conclusion}

Having identified the South African efforts that are aimed at averting poverty, this article has also gone a step further in analysing the pros and cons of these strategies. The analytical and microscopic eyes of the researchers intended to bring out the prevalence of poverty in South Africa, a nation that is celebrating its twentieth independence since the apartheid era. This enables further probing into the matters concerned in order to unearth constructive strategies that can put African countries such as South Africa on a global map. As it is always said that there are two sides to every coin, these researchers have recommended measures that can enable South Africa to be a better country for all. It is a pity that the country, one of the African's economic powerhouses, is slowly sliding into a state of disrepute through ever burgeoning cases of indigent people. This is ironic and somehow unacceptable after two decades since the apartheid ended. The government needs to re-evaluate and reconsider its poverty alleviation policies.

\section{References}

Alao, A. (2012). Mugabe and the Politics of Security in Zimbabwe. Canada: McGill-Queen's University.

Blakemore, F.L.E. (2003). A Panel Data Analysis of Crime in South Africa. SAJEMS NS 6 No. 3439.

Bradshaw, T.K. (2005). Theories of Poverty and Anti-Poverty Programmes in Community Development. University of California: Davis.

Brady, D. (2009). Rich Democracies, Poor people: How Politics Explains poverty. Oxford University: New York.

Chant, S. (2006). Re-thinking the "Feminization of Poverty" in Relation to Aggregate Gender Indices. Journal of Human Development. Vol \&, No. 2. Page 1-20.

Ditmore, M.H. (2011). Historical Guide to Controversial Issues In America: Prostitution and Sex Work. Greenwood: California.

Economic Report on Africa. (2005). Meeting the challenges of unemployment and poverty in Africa. Economic Commission for Africa: Addis Ababa.

eNCA @ 17:30 hrs NEWS, 06/01/2014

eNEWS @ 18:00Hrs, 21/02/2014

Gilbert, G. (2004). World Poverty: A reference Handbook. Carlifonia: Liabrary of Congress.

Hanlon J, Barrientos, A. \& Hulme, D. (2010). Just Give Money to the Poor: The Development Revolution from the Global Brief No 5. RHVP.

Kanchense, J. (2008). Zimbabwe's Child Brides: Using participatory Action to unleash Human Potential. Victoria: Trafford.

Kang'ethe, SM. (2009). The challenge that Aging of caregivers poses to the quality of Care Giving with reference to Kanye Community Home Based Care Programme. Botswana Notes and Records (BNR) Journal. 2009. Vol. 41. Pp76-82.

Kange'the, SM \& Mafa, I. (2014). Dynamics associated with matrifocality in Zimbabwe: A Literature Review. Accepted for publication by the Journal of Sociology and sociological anthropology, India.

Kangethe, S.M. \& Manomano, T. (2014). Validating RDP Housing Beneficiaries' Perceptions on the quality of Their houses. The case of RDP Golf Course Study, Eastern cape. In the press of Journal of Human Ecology, India.

Kotch, J.B. (2013). Maternal and Child Health: Programmes, Problems and Policy In Public Health. Jones and Barlett Learning Books: Burlington.

MacArthur, J. (1997). The MacArthur Holy Study Bible. Dallas. Word publishing

Makina, D. \& Kanyenze, G. (2010). The Potential Contribution of the Zimbabwe Diaspora to the Economy's Recovery. Harare: UNDP.

Manomano, T. (2013). The perceptions of the Reconstruction and Development Programme (RDP) Housing beneficiaries in South Africa on the extent to which the project meet their Housing needs: The case of Golf Course Estate in Alice Town, Eastern Cape Province. Masters Dissertation. South Africa: University of Fort Hare.

Mbuli, B.N. (2008). Poverty Reduction Strategies in South Africa. University of South Africa. 
Moyo, S. (2005). Land Policy, Poverty Reduction and Public Action in Zimbabwe. New York. ISS/UNDP Poverty and Public Action Paper No. 11.

Musekiwa, P. (2013). Livelihood Strategies of female-headed Households in Zimbabwe. The case of Magaso Village, Mutoko District in Zimbabwe. Unpublished Masters in Social Work Dissertation, Social Work Department, Faculty of Social Sciences, University of Fort hare

Potty, R. (2012). Social Welfare in SA: Curing or Causing Poverty? American University.

Reddy, T. \& Sokamani, A. (2008). Corruption and Social Grants in SA. Monograph.

Rodgers-Dillon, RH. (2004). Welfare Experiments: Politics and Policy Evaluation. Stanford University: California.

Saleebey, D. (Ed.). (2005). The strengths perspective in social work practice (4th ed.). New York: Longman.

Scott, J. (2008). Social Protection: Top Priority to end Chronic Poverty. CPRC Policy Brief 9. Manchester, UK: Chronic Research Centre (CPRC).

Shepherd, A, Wadagodapitiya, D. \& Evans, A. (2011). Policy Brief: Social Assistance and the Dependency Syndrome. No 22. Chronic Poverty Research Centre.

Skweyya, Z. (2007). Social Development Budget. 2007/08 28 March.

UNAIDS (2004). AIDS Epidemic Update. Geneva.

Vicente, E. (2005). From the Feminization of Poverty to the Feminization and Democratization of Power: SELA 2005 Panel 1: The Obligation to Eradicate Poverty. McMillan: London.

Wahba, MA \& Bridwell, LG. (1976). Maslow Reconsidered. A review of research on the need hierarchy theory. Organizational Behaviour and Human Performance. Vol. 15, Issue 2, April 1976. Pg 212-240.

Ward, LM \& Eyber, C. (2009). Resiliency of children in child-headed households in Rwanda: Implications for Community Based psychosocial Interventions. Intervention, 7(1), 17- 33.

White Paper for Social Welfare. (1997). Principles, Guidelines, Recommendations, Proposed Policies and Programmes for Developmental Social Welfare in South Africa. Pretoria.

World Bank. (2014). South Africa Overview. Accessed at: http://www.worldbank.org/en/country/southafrica/overview .

Yarber, A.D. \& Sharp, P.M. (2010). Focus on the Single Parents families: Past Present and Future. Greenwood: California.

Zastraw, C. (2010). The Practise of Social Work: A comprehensive Worktext. 9th edition. Brooks/ Coles Press: Belmont.

ZBC NEWS 20:00 hrs, 04/01/2014 